\title{
ДОСВІД ОСВОЄННЯ ПРАКТИЧНИХ НАВИЧОК СТУДЕНТАМИ НА КАФЕДРІ ПРОПЕДЕВТИКИ ВНУТРІШНЬОЇ МЕДИЦИНИ В УМОВАХ СИМУЛЯЦІЙНОГО ЦЕНТРУ
}

\author{
С. М. Андрейчин, Н. А. Бількевич, Т. Ю. Чернець, Б. Г. Бугай, В. О. Лихацька, \\ Н. Я. Верещагіна, Н. А. Кавецька, П. П. Кузів, М. М. Руда, Н. З. Ярема, \\ I. I. Ганьбергер, С. В. Кучер \\ ДВНЗ “Тернопільський державний медичний університет імені I. Я. Горбачевського \\ МОЗ України”
}

\section{THE EXPERIENCE OF PRACTICAL SKILLS MASTERING BY STUDENTS AT THE INTERNAL MEDICINE PROPEUDETICS DEPARTMENT IN THE PERMISSES OF SIMULATION CENTRE}

\author{
S. M. Andreychyn, N. A. Bilkevych, T. Yu. Chernets, B. H. Buhai, V. O. Lykhatska, \\ N. Ya. Vereshchahina, N. A. Kavetska, P. P. Kuziv, M. M. Ruda, N. Z. Yarema, \\ I. I. Hanberher, S. V. Kucher \\ I. Horbachevsky Ternopil State Medical University
}

\begin{abstract}
У статті розглянуто можливості методу симуляційного навчання у світлі сучасних уявлень про процес засвоєння інформації та набуття практичних компетенцій. Проаналізовано власний досвід проведення практичних занять для студентів II-III курсів медичного університету на основі наявних у наукових публікаціях даних про результати впровадження методу симуляційного навчання у медичних вищих навчальних закладах України.

The article adduces the method of simulation training opportunities in the light of modern ideas about the process of information assimilation and the acquisition of practical skills. The authors analyzed their own experience of practical classes conduction for the $2^{\text {nd }}-$ and $3^{\text {rd }}$-year students of medical university. The analysis is made taking into account the existing scientific publications data about simulation training method implementation in medical higher educational institutions of Ukraine.
\end{abstract}

Вступ. Сучасні реалії ставлять перед медичною освітою завдання підготовки конкурентоспроможних та професійно компетентних спеціалістів [1, 2]. Одним з головних пріоритетів є практична орієнтація навчального процесу при збереженні належного рівня теоретичних знань [3-5].

Медична освіта в Україні поступово долає однобоку когнітивну направленість навчання, основану значною мірою на теоретичній підготовці. Згідно 3 сучасними концепціями психології та теорії інформації [6, 7], процес сприйняття, засвоєння і практичного використання знань людиною підлягає певним законам. Уся інформація, яка надходить до нас як ззовні, так і зсередини (інформація про психофізичний стан людини), - це єдиний інформаційний потік, який розщеплюється психікою людини на

(c) С. М. Андрейчин, Н. А. Бількевич, Т. Ю. Чернець та ін. окремі складові. Існує декілька каналів сприйняття інформації, і логічний канал (міркування, висновки, докази) є лише одним із них. До інших каналів сприйняття інформації належать сенсорні відчуття (слухові, зорові, тактильні, нюхові та сенсомоторні, що надходять зсередини організму), емоції та стосунки між людьми та деякі інші. Прийом і обробка кожної з цих складових може бути здійснена лише каналом, відповідним до сорту інформації [6-8]. Це означає, зокрема, що студенту важко повноцінно сприйняти сенсорну інформацію (наприклад, що стосується огляду хворого, пальпації, перкусії, аускультації) з теоретичних викладок, такий матеріал повинен бути підкріплений сенсорними відчуттями. Крім того, згідно з теорією інформації, психічний апарат людини побудований так, як і будь-яка інша інформаційна система. Людина 
сприймає факти реальної дійсності через відчуття $\rightarrow$ утворює образні уявлення через поняття, що зберігаються в пам’яті $\rightarrow$ зіставляє старі та нові поняття між собою, аналізує їх несуперечливість $\rightarrow$ робить висновок (суперечить чи не суперечить інформація основним цінностям, установкам тощо). При цьому сприйняття інформації органами чуттів $є$ лише першим етапом навчання, надалі вона повинна бути оброблена в зазначеному порядку й оцінена (формування висновку). Лише такі знання формують досвід і практичну компетентність спеціаліста [6-8].

Врахування цих законів функціонування психіки людини зумовило б покращення підготовки студентів медичних ВН3. Саме тому в практику викладання все ширше впроваджують унаочнення теоретичного матеріалу (ілюстрації, презентації, відео-, аудіозаписи тощо), адже це дає можливість сприйняття інформації сенсорним шляхом. Ще більш ефективними є освітні методики, які задіюють у процес навчання усі канали збору інформації і включають повний цикл їі засвоєння від сприйняття до висновків. Такими є проблемно-орієнтоване і симуляційне навчання [5, 9, 10], що активно впроваджуються у ВНЗ України останніми роками $[3,4]$. Використання віртуальних технологій та різного роду симуляторів дозволяє з тим або іншим ступенем достовірності моделювати процеси, ситуації та інші аспекти професійної діяльності медичних працівників [3, 4, 9].

Найбільшого поширення застосування симуляторів з навчальною метою набуло у галузях діяльності людини, які передбачають високі ризики [3, 4, 9], коли помилка працівника може бути причиною загибелі людей або значних матеріальних втрат $[3,5]$. Такими ситуаціями в медицині, безперечно, $€$ невідкладні стани, хірургічні та парентеральні втручання, робота з дорогим обладнанням. Використання симуляторів, манекенів, фантомів дозволяє багаторазово відпрацьовувати певні дії до повної досконалості при забезпеченні своєчасних, докладних професійних інструкцій в ході роботи [3-5]. Крім того, в сучасних реаліях у клініці часто важко знайти тематичного хворого для демонстрації студентам синхронно із вивченням тієї чи іншої теми, студенти працюють у великих групах, що теж обмежує їх доступ до пацієнтів. Тому можливість відтворення ситуацій, що трапляються в клінічній практиці, особливо рідких, є ще одним позитивним моментом такого навчання [3-5]. Проте найбільшою перевагою є те, що симуляційні методи навчання $є$ практично-орієнтованими. У процесі спеціально організованого інтерактивного спілкування з викладачем (тренером-експертом) та іншими студентами в команді, переживаючи певну реальну ситуацію та виконуючи певні дії, студент набуває досвіду пошуку “нових” знань і усунення власних помилок, проходить повний цикл засвоєння інформації з формуванням висновків [3-5].

Оскільки симуляційне навчання почало активно впроваджуватись в освітній процес медичних ВНЗ України лише останніми роками, його методологічна база розвивається і будь-який новий практичний досвід $є$ корисним. Для того щоб ці (дорогі) технології принесли максимальну користь, актуальним $є$ визначення їх конкретних переваг і недоліків, розробка, цілей і завдань навчального процесу, методики проведення занять [9], що активно відбувається останніми роками в Україні $[3,4]$. Симуляційне навчання - складний процес, який для ефективного вирішення поставлених завдань повинен мати певну тривалість. У практику деяких ВНЗ введене поняття стандартного імітаційного модуля (CIM) як одиниці навчального процесу, відведеної на безпосередню взаємодію студентів із засобами навчання з певної теми під педагогічним контролем. СІМ включає в себе перелік практичних навичок, об’єднаних за тематичним принципом, які будуть сформовані (проконтрольовані) у студентів протягом цього часу. Кожна така одиниця має сформульований кінцевий результат підготовки, i ïi тривалість становить 3 години [9].

Основна частина. Відкриття Центру симуляційного навчання в ТДМУ ім. І. Я. Горбачевського у вересні 2016 р. дало довоочікувану можливість викладачам нашого ВНЗ проводити симуляційні навчання із студентами. Протягом семестру роботи у центрі з'явився поки ще невеликий досвід і у викладачів кафедри пропедевтики внутрішньої медицини. Метою нашої публікації було проаналізувати цей досвід для покращення проведення навчального процесу в майбутньому.

Викладачами кафедри на базі Центру симуляційного навчання протягом осіннього семестру 2016 року організовано та проведено практичні заняття 3 трьох тем. Тривалість одного заняття становила 2 академічні години. Тематикою двох занять, проведених для студентів III курсу медичного та II курсу стоматологічного факультету в рамках предмета “Пропедевтика внутрішньої медицини”, була аускультація легень та серця. Актуальність проведення такого заняття в симуляційному центрі 
полягає в тому, що в умовах стаціонару студенти не завжди мають достатню можливість проводити це обстеження при різній патології, деякі захворювання рідко трапляються в клініці. Крім того, оволодіння навичками діагностики патологічних змін при аускультації вимагає багаторазового прослуховування, що неможливо при роботі з пацієнтом, особливо у великих групах студентів.

Заняття проводили з використанням манекена американської фірми Gaumard, що являв собою торс людини. Манекен оснащений віртуальним фонендоскопом, який забезпечував вислуховування точок аускультації серця і легень та відтворення аускультативних феноменів у нормі і при патології. На початку заняття студенти вислуховували дихальні шуми (чи серцеві тони - залежно від теми заняття) один на одному, тренуючись розпізнавати звукові явища в нормі. Після цього викладач демонстрував на манекені звукові феномени, які виникають при аускультації в різних патологічних станах, одночасно наводячи їх графічну реєстрацію для наочного сприйняття. Далі студенти ділились на групи по 4-5 осіб, де кожен отримував завдання самостійно вислухати точки аускультації на фантомі в одному з режимів та охарактеризувати ці звукові явища згідно зі схемою, наведеною в методичних рекомендаціях. Для правильного виконання практичних навичок було розроблено алгоритми їх виконання. На завершення викладач оцінював якість виконання студентами аускультації та їх вміння інтерпретувати дані цього методу обстеження при патології згідно зі схемою (основні дихальні шуми - побічні дихальні шуми або основні тони серця - додаткові тони серця - шуми). 3 цією метою розробили критерії оцінювання на основі алгоритмів практичних навичок. Закінчувалось заняття підсумками, що включали аналіз проведеної роботи та допущених помилок.

Одне практичне заняття для студентів III курсу медичного факультету з предмета “Сестринська практика” проводили у спеціально оснащеному залі для проведення медичних маніпуляцій. Тематикою заняття стало відпрацювання техніки виконання підшкірних, внутрішньошкірних, внутрішньом'язових та внутрішньовенних ін'єкцій. Зал медичних маніпуляцій симуляційного центру ТДМУ оснащений сучасними тренажерами 3 можливістю проведення на них ін'єкцій, імітацією підшкірних вен та візуалізацією течії крові (фарбований червоним кольором розчин). Дане оснащення давало змогу реалістично симулювати проведення маніпуляції: можливість пальпаторного відчуття заповненої кров’ю вени, відчуття “провалу”, появи крові у шприці при аспірації. Структура заняття була аналогічна до наведеної вище: вступна частина - демонстрація методики виконання усіх типів ін’єкцій викладачем згідно зі стандартними алгоритмами - практична робота студентів оцінювання - підсумки.

Слід зазначити, що така форма навчання була дуже позитивно сприйнята студентами, вони активно працювали над засвоєнням практичних навичок. Позитивним є те, що студенти мають можливість послухати такі аускультативні феномени, які рідко трапляються у клініці. Після тренування вони легко починали розрізняти, наприклад, третій та четвертий тони серця в складі ритму галопу, тон відкриття мітрального клапана та ритм перепела, дрібноміхурцеві та великоміхурцеві вологі хрипи тощо. Ефективність навчання зростала, якщо викладач використовував графічну демонстрацію цих звукових явищ.

3 досвіду проведення заняття із застосуванням симуляційних методик, що співзвучно з деякими авторами [5], оптимальним є його побудова за етапами. Першим етапом $є$ теоретична підготовка студентів, причому навчальний матеріал повинен бути побудований на даних доказової медицини та загальноприйнятих стандартах діагностики i лікування. Наступним етапом є освоєння практичних навичок на тренажерах. За ним йде етап комп’ютерної імітації, коли в умовах класу студент проходить певні модулі інтерактивної навчальної програми з певної навички. Після цього студент потрапляє в симуляційну частину центру (імітація палати), де в наближених до реальних умовах він шляхом багаторазового повторення і роботи над помилками домагається досконалості своїх психомоторних навичок, навичок роботи з обладнанням і пацієнтом, навичок роботи в команді [5]. Така етапність може бути дотримана, коли заняття в симуляційному центрі проводять, починаючи 3 II-III курсів ВНЗ і протягом усіх подальших років навчання - до складніших етапів симуляційного навчання.

Симуляційні тренінги поділяють на прості й комплексні [9]. Прості тренінги спрямовані на формування репродуктивної діяльності, де потрібно якомога менше думати, але при цьому діяти вірно і більше інтелектуальних ресурсів економити для дій з урахуванням конкретних обставин. Результатом простого тренінгу є відпрацювання нової практич- 
ної навички. Такий тренінг має чотирьохетапний підхід: демонстрація еталонного виконання - демонстрація еталонного виконання з поясненнями інструктора (тренера) - демонстрація еталонного виконання з поясненням студентів - виконання навички студентами. Саме така схема була опрацьована нами і показала свою ефективність у навчальному процесі студентів 2-3 курсів. Комплексні тренінги спрямовані на залучення в практику інтелекту студентів, вдосконалення креативної діяльності. Такі тренінги не мають на меті формування нових навичок, а закріплюють вже наявні, вдосконалюють їх. Проведення комплексного тренінгу відбувається у три етапи: спроба виконання завдання студентами - спільне вироблення рекомендацій щодо вдосконалення - виконання завдання з використанням вироблених рекомендацій $[5,9]$.

Вважаємо, що введена нами форма проведення практичних занять на базі Центру симуляційного навчання досягла своєї мети - відпрацювання ба-

\section{Список літератури}

1. Як удосконалити медичну освіту // Медична академія. - 2016. - № 17. - С. 2-3.

2. Впровадження принципів Болонського процесу у навчання студентів на кафедрі пропедевтики внутрішньої медицини та фтизіатрії / С. М. Андрейчин, Н. 3. Ярема, Т. Ю. Чернець [та ін.] // Проблеми інтеграції української медичної освіти у світовий освітній простір : матеріали Всеукр. навч.-наук. конф., 21-22 травня 2009 року, м. Тернопіль. - Тернопіль : ТДМУ, 2009. - С. 159-161.

3. Симуляционное обучение при лечении неотложных состояний в медицине / В. В. Артеменко, В. М. Носенко, Р. С. Вастьянов [и др.] // Досягнення біології та медицини. - 2015. - № 2. - С. 58-64.

4. Симуляційне навчання в медицині: міжнародний i вітчизняний досвід / В. В. Артьоменко, С. С. Семченко, О. С. Єгоренко [та ін.] // Одеський медичний журнал. 2005. - № 6 (152). - С. 67-74.

5. Муравьев К. А. Симуляционное обучение в медицинском образовании - переломный момент/ К. А. Муравьев, А. Б. Ходжаян, С. В. Рой // Фундаментальные исследования. - 2011. - № 10, ч. 3. - С. 534-537. зових практичних навичок студентів. Така форма $є$ адаптованою до рівня володіння предметом студентами початкових курсів, які тільки-но прийшли у клініку і лише починають вивчати ази внутрішньої медицини в частині фізикального обстеження пацієнта. Для студентів старших курсів, які вже оволоділи методиками обстеження хворого, вивчили лабораторні та інструментальні методи їх обстеження, слід розробляти комплексні заняття із симуляцією клінічних ситуацій.

Висновки. Симуляційне навчання $є$ дієвим й ефективним інструментом для трансформації теоретичних знань студентів у практичну площину, тому необхідне широке впровадження його в навчальний процес у медичному ВНЗ. 3 метою оптимізації процесу навчання та раціонального застосування даного методу потрібно розробити підходи до поетапного нарощування складності занять, загальні вимоги до їх тривалості, об’єму практичної роботи на занятті.

6. Гуленко В. В. Практикум по соционике / В. В. Гуленко. - Минск : Современная школа, 2008. - 216 с.

7. Прокофьева Т. Н. Соционика для профессионалов. Соционические технологии в педагогике и управлении персоналом / Т. Н. Прокофьева, В. Г. Прокофьев, А. С. Девяткин ; под общ. ред. Т. Н. Прокофьевой. - М. : Изд-во “Алмаз” , 2008. - 323 с.

8. Добрынина Т. Н. Педагогические условия применения интерактивных форм обучения в педагогическом вузе : дисс.... канд. пед. наук: 13.00.01 / Т. Н. Добрынина. - Новосибирск, 2003. - 196 с.

9. Свистунов А. А. Методы и принципы симуляционного обучения / А. А. Свистунов. - http://rosomed.ru/ kniga/metodi_i_principi_simulationnogo_obucheniya.pdf.

10. Шеремета П. М. Кейс-метод: $з$ досвіду викладання в українській бізнес-школі / П. М. Шеремета, Л. Г. Каніщенко ; за ред. О. І. Сидоренка. - 2-ге видання. - К. : Центр інновацій та розвитку, 1999. - 80 с.

Отримано 04.11.16 